\title{
Improvement of Phenols Production by Amino Acids in Callus Cultures of Verbascum thapsus L.
}

\author{
Abedaljasim M. Jasim Al-Jibouri'1, Ashwaq S. Abed1", Abdal-Jabbar Abass Ali², \\ Duha M. Majeed 1 \\ ${ }^{1}$ Biotechnology Research Center, Al-Nahrain University, Baghdad, Iraq \\ ${ }^{2}$ Ministry of Science and Technology, Baghdad, Iraq \\ Email: "ashwaqbio@yahoo.com
}

Received 18 November 2015; accepted 18 January 2016; published 21 January 2016

Copyright (C) 2016 by authors and Scientific Research Publishing Inc.

This work is licensed under the Creative Commons Attribution International License (CC BY). http://creativecommons.org/licenses/by/4.0/

(c) (i) Open Access

\section{Abstract}

A great mullein (Verbascum thapsus L.) was a famous species in Scrophulariaceae family. It was generally used as herbal medicine. Explants of $V$. thapsus (leaves and petioles) were cultured in vitro on Murashige and Skoog (MS) medium for shoot proliferation.Plantlet explants were cultured on MS medium supplemented with combination of Benzyl adenine (BA) and Naphthalene acetic acid (NAA) for callus induction. The best fresh and dry weight of callus formation was achieved using $0.5 \mathrm{mg} / \mathrm{l}$ BA. Quantitative analyses with High-performance liquid chromatography (HPLC) showed the content of phenols like Coumarin, Eugenol and Thymol were relatively low in leaves of mother plant, $(10,41,310 \mathrm{ppm})$ respectively. The addition of different concentrations of amino acids as a precursor adding separately to the tissue culture medium led to raise the accumulation levels of phenolic compounds in callus tissue. Generally, the enhancement of accumulation depended on the type of amino acids and their concentration. The results showed $150 \mathrm{mg} / \mathrm{l} \mathrm{of}$ Proline encouraged production of Comarin to $2752 \%$, while $50 \mathrm{mg} / \mathrm{l}$ of Proline promoted accumulation of Eugenol to $290 \%$. Whilst $150 \mathrm{mg} / \mathrm{l}$ of Tryptophan increased production of Thymol to $390 \%$, in comparison with mother plant.

\section{Keywords}

Verbascum thapsus, Comarin, Eugenol, Thymol, Amino Acids

\section{Introduction}

Verbascum is a genus of about 360 species of flowering plants in the Scrophulariaceae family. They are native *Corresponding author.

How to cite this paper: Al-Jibouri, A.M.J., Abed, A.S., Ali, A.-J.A. and Majeed, D.M. (2016) Improvement of Phenols Production by Amino Acids in Callus Cultures of Verbascum thapsus L. American Journal of Plant Sciences, 7, 84-91. 
to Europe and Asia, with the highest species diversity in the Mediterranean and Iranian Altoranih [1] [2]. The most important species is Verbascum thapsus L. Common names include mullein, common mullein, great mullein, wooly mullein, candlewick plant, velvet plant, blanket leaf, Aaron's rod, Jacob’s staff, hedge taper, high taper, old man's flannel [3].

$V$. thapsus is rich plant in Phenolsso, it may be used wisely as an alternative medicine, it has been used as antiseptic, demulcent, narcotic, diuretic and has anti-microbial, anti-malarial, anti-oxidant and anti-inflammatory activities [4]-[7]. An aromatic, slightly bitter tea can be made by infusing dried leaves in boiling water [8]. The flowering stems can be dipped in wax and be used as torches and to make wicks for candle [9].

Plant phenols are secondary metabolites with diverse chemical nature and potential including: phenolic acids, flavonoids, tannins, coumarins, lignans and xanthones. Phenols are providing essential functions in the reproduction and the growth of the plants acting as defense mechanisms against pathogens, parasites, and predators [4] [10]. Plant tissue culture techniques are used as an alternative method for production and accumulation of secondary metabolites in situations when plant material is rare or difficult to acquire and when chemical synthesis of their metabolites is low or not possible [11].

Several endeavors have been recorded for enhanced synthesis of secondary metabolites in vitro cultures of different plant species, e.g. flavonoid productionin cultured tissue of Hydrocotyle bonariensis [12], Tropanealkaloids in Hyoscyamus niger [13], indole alkaloid in Catharanthus roseus [14], essential oil in Origanum vulgare L. and Calendula officinalis L. [15] [16].

Many researchers refer that metabolic engineering seems a promising approach to improve the cells production. So this study is conducted to experience the effect of amino acids as precursor feeding on the enhancement of phenolic compound accumulation in vitro.

\section{Material and Methods}

\subsection{Source of Plant}

Common mullein plants, Verbascum thapsus L. were collected at flowering stage from Al-Sulaimania mountains, Iraq on April 2013. In vitro plantlets were established according to Turker et al. [17]. Plantlet explants were used for induction of callus using (MS) medium [18] supplemented with different concentration of auxin 2,4-D (0, 0.5, 1 and $1.5 \mathrm{mg} / \mathrm{l})$ and cytokinin BA (0, 0.5, 1, and $1.5 \mathrm{mg} / \mathrm{l})$. Fresh and dry weights callus were measured after 6 weeksof incubation at $25^{\circ} \mathrm{C} \pm 2{ }^{\circ} \mathrm{C}$ and $16 \mathrm{hrs}$ light. The best callus production was selected after 6 weeks for further work. These callus were sub cultured each 4 weeks on fresh media supplemented with 0.5 $\mathrm{mg} / \mathrm{L}$ of BA, and for two months continuously to maintain callus stock. An equal fresh weight of callus about (300 mg) was cultured on same medium which used in callus maintenance. Three concentrations 50, 100 and $150 \mathrm{mg} / \mathrm{l}$ of four different sources of amino acids: Proline, Glutamine, Tryptophan and Phenylalanine were used separately as precursor feeding for accumulation of phenolic compounds such as, Coumarin, Eugenol, and Thymol.

\subsection{Extraction of Plant Materials}

Leaves of mother plant and callus tissue were dried at $45^{\circ} \mathrm{C}$ in oven for $48 \mathrm{hrs}$, and then kept at $4^{\circ} \mathrm{C}$. A $200 \mathrm{mg}$ of dried plant material was taken for phenols extraction; the aliquots were shaken in $5 \mathrm{ml}$ of methanol and incubated at room temperature for overnight. Plant material was centrifuged and filtered out using Whatman No.1, and $3 \mathrm{ml}$ aliquots from each filtrate were filtered again using $0.22 \mu \mathrm{m}$ syringe filters [19]. The existence and content of Coumarin, Eugenoland Thymol of callus tissue analyzed by HPLC. The leaves of mother plant were also analyzed for comparison.

\subsection{Chromatographic (HPLC) Conditions}

The RP-HPLC (Sykum-German) system with C18 reversed-phase column $(250 \times 4.6 \mathrm{~mm})$ was used to detect of phenolic compound, Coumarin, Eugenol and Thymol. Acetonitrile and water in 75:25 (v/v) ratios was chosen as the mobile phase under a column temperature of $30^{\circ} \mathrm{C}$. The detection wavelength was set at $210 \mathrm{~nm}$ with a flow rate of $1.4 \mathrm{ml} / \mathrm{min}$; the auto sampler injection volume was $20 \mu \mathrm{l}$. Quantitative method was analyzed by external standard. All standards were obtained from Sigma-Aldrich (USA). 


\subsection{Statistical Analysis}

All experiments were carried out in 15 replicates. The experiment results were statistically analyzed by ANOVA with Two-way Analysis of Variance test using MINITAB11 statistical program. Experiments were carried out with completely randomized block design and the differences between groups were compared using LSD at $P \leq$ 0.05 .

\section{Results and Discussion}

\subsection{Callus Production}

Data recorded in Table 1 showed the presence of significant effects of growth regulators used on callus production from plantlet explants. The best result of callus production was recorded with $0.5 \mathrm{mg} / \mathrm{l}$ of BA done highest value of mass callus production, (3672 and $218 \mathrm{mg}$ ) in fresh and dry weight respectively. The combination between BA and 2,4-D caused positive significant effect on fresh and dry weight of callus. However, supplementation of MS media with 2,4-D alone showed a little effect on callus production. Similar results were reported for callus induction from Verbascum sinuatum L. [20], they stated that a callus induction was induced on MS medium supplemented with different concentrations of BA and NAA, but no induction of callus was observed using NAA alone.

Callus inductions depended on kind and concentration of plant growth regulators, type of explant also played a considerable role in callus induction [21]. So the plantlet explant was selected in our study for initiation of callus according with [20] [22], they successfully, initiated the callus tissue of $V$. speciosum and $V$. sinuatum L.

\subsection{Effect of Amino Acids on Mass Growth of Callus Culture}

All treatments of amino acids (Proline, Glutamine, Tryptophan and Phenylalanine), gave different mass value of callus tissue. Generally, $150 \mathrm{mg} / \mathrm{L}$ of Glutamine added to MS medium done high response of fresh and dry weight reached to (3065 and $160 \mathrm{mg}$ ) respectively, (Table 2). Significantly, none of amino acids tested promoted production of callus. The results were in agreement with Urmantsva et al. [23], were found that of none of the amino acids tested enhanced biomass production in cell cultures of Thalictrum minus.

Table 1. Effect of 2,4-D and BA concentrations and their combinations on fresh and dry weight (mg) of callus induction on MS medium from plantlet explant of $V$. thapsus.

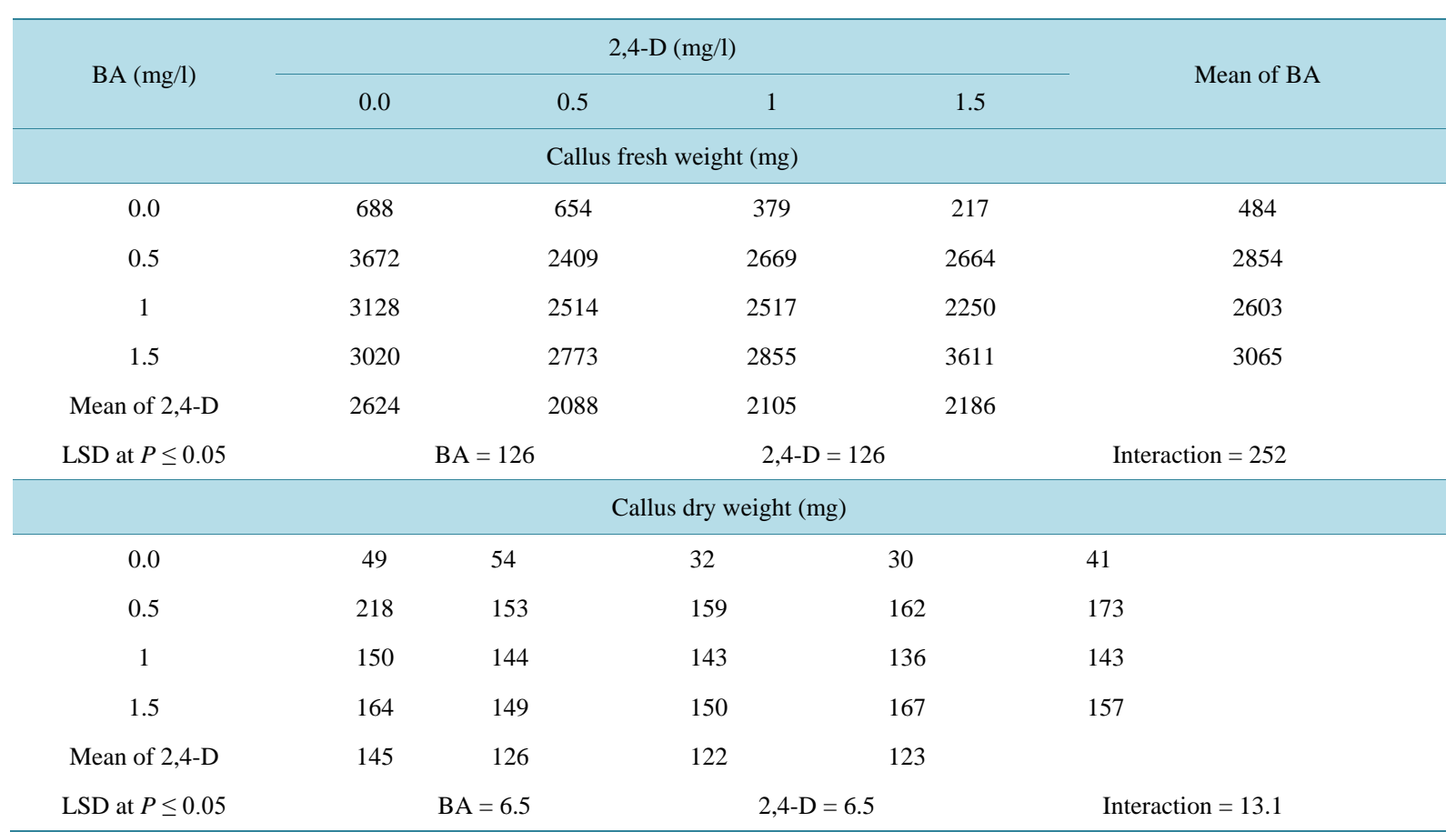


Table 2. Effect of different concentration of amino acids (mg/l) added to MS medium on callus fresh and dry weight of $V$. thapsus L. after 4 weeks of incubation (initial callus weight was $300 \mathrm{mg}$ ).

\begin{tabular}{|c|c|c|c|c|}
\hline \multirow{2}{*}{ Concentration of amino acid (mg/l) } & \multicolumn{4}{|c|}{ Amino acid } \\
\hline & Proline & Glutamine & Tryptophan & Phenyl alanine \\
\hline \multicolumn{5}{|c|}{ Callus fresh weight (mg) } \\
\hline 0.0 & 2548 & 2548 & 2548 & 2548 \\
\hline 50 & 2758 & 2887 & 2857 & 2244 \\
\hline 100 & 2193 & 2923 & 2951 & 1923 \\
\hline 150 & 2112 & 3065 & 2709 & 2045 \\
\hline Mean & 2402 & 2855 & 2766 & 2190 \\
\hline \multicolumn{5}{|c|}{ No statistically significant differences at $P \leq 0.05$} \\
\hline \multicolumn{5}{|c|}{ Callus dry weight (mg) } \\
\hline 0.0 & 141 & 141 & 141 & 141 \\
\hline 50 & 159 & 153 & 157 & 139 \\
\hline 100 & 138 & 156 & 165 & 138 \\
\hline 150 & 137 & 160 & 158 & 141 \\
\hline Mean & 143 & 152 & 155 & 139 \\
\hline \multicolumn{5}{|c|}{ No statistically significant differences at $P \leq 0.05$} \\
\hline
\end{tabular}

The use of amino acids as an organic source of nitrogen was not usually desired in modern media, where a proper balance between $\mathrm{NO}_{3}^{-} / \mathrm{NH}^{+}$guaranteed the nitrogen requirement, L. glutamine was most commonly used as a nitrogen source in tissue culture [21].

\subsection{Effect of Amino Acids on Accumulation of Phenolic Compound in Callus Culture of $V$. thapsus}

The results in Table 3 showed the low content of Coumarin (10 ppm) which achieved at mother plants, while in vitro callus tissues extract gave high significant values especially with amino acids treatments. It was noted that the addition of high concentration of Proline, Tryptophan and Phenylalanine $(150 \mathrm{mg} / \mathrm{l})$ led to produce high significant values of Coumarin (285.2, 88.2 and 146.8 ppm) respectively. Prolineat concentration of $150 \mathrm{mg} / \mathrm{l} \mathrm{suc-}$ cessfully trigged the production of Coumarin (285.2 ppm), which was $2752 \%$ higher than mother plant. While the lowest concentration of Glutamine $50 \mathrm{mg} / \mathrm{l}$ gave the best production of Coumarin (113.2 ppm), 1032\% more than mother plant.

Although Eugenol was scarcely detected $(15.0 \mathrm{ppm})$ in callus culture of control treatment, (Table 4). This compound was highly produced when the callus was treated with low concentration of amino acids (50 and 100 $\mathrm{mg} / \mathrm{l})$. Treatment with Proline at $50 \mathrm{mg} / \mathrm{l}$ gave high percentage of increase; it was $290 \%$ more than mother plants, (Figure 1). On the other hand, similar values of Eugenol production (71.8, 68.0 and $74.9 \mathrm{ppm}$ ) were recorded in Glutamine treatments (50, 100 and $150 \mathrm{mg} / \mathrm{l})$ respectively, with percentage of increasing ranged between (65\% 82\%) more than mother plant.

The results illustrated in Table 5 indicated that addition of Tryptophan and Phenylalanine as precursors led to increase the production of Thymol. The superiority in Thymol production was attained in medium contained 150 mg/l of Tryptophan, it was (1518.8 ppm), 390\% higher compared with mother plants. Supplementation with both amino acids (Proline and Glutamine) as precursors caused reduction in Thymol concentrations to percentage of 30.97\%, 95.66\% and 38.60\% respectively, compared with the control and mother plant.

Attempts to induce the yield of the secondary product by supplying precursors or abiotic elicitors are found to be effective in many cases. Amino acids have been used as organic nitrogen source in in vitro cultures of several 
Table 3. Effect of amino acid added to MS medium on accumulation of Coumarin (ppm) in callus culture of V. thapsus after 4 weeks of incubation.

\begin{tabular}{|c|c|c|c|c|}
\hline \multicolumn{2}{|l|}{ Concentration of amino acid (mg/l) } & \multirow{2}{*}{$\begin{array}{c}\text { Coumarin (ppm) } \\
10\end{array}$} & \multirow[t]{2}{*}{$\begin{array}{l}\text { Percentage (\%) of Increase } \\
\text { compared with mother plants }(+)\end{array}$} & \multirow[t]{2}{*}{$\begin{array}{l}\text { Percentage (\%) of decrease } \\
\text { compared with mother plants (-) }\end{array}$} \\
\hline Mother plants (leaves) & & & & \\
\hline Control (callus without amino acid) & 0.0 & 90.2 & +802 & \\
\hline & 50 & 178.9 & +1689 & \\
\hline \multirow[t]{3}{*}{ Proline } & 100 & 121.8 & +1118 & \\
\hline & 150 & 285.2 & +2752 & \\
\hline & 50 & 113.2 & +1032 & \\
\hline \multirow[t]{3}{*}{ Glutamine } & 100 & 70.0 & +600 & \\
\hline & 150 & 41.1 & +311 & \\
\hline & 50 & 70.7 & +607 & \\
\hline \multirow[t]{3}{*}{ Tryptophan } & 100 & 70.4 & +604 & \\
\hline & 150 & 88.2 & +782 & \\
\hline & 50 & 45 & +350 & \\
\hline \multirow[t]{2}{*}{ Phenyl alanine } & 100 & 122.3 & +1123 & \\
\hline & 150 & 146.8 & +1368 & \\
\hline
\end{tabular}

Table 4. Effect of amino acid added to MS medium accumulation of Eugenol (ppm) in callus culture of V. thapsus after 4 weeks of incubation.

\begin{tabular}{|c|c|c|c|c|}
\hline \multicolumn{2}{|l|}{ Concentration of amino acid (mg/l) } & \multirow{2}{*}{$\begin{array}{c}\text { Eugenol (ppm) } \\
41.0\end{array}$} & \multirow[t]{2}{*}{$\begin{array}{l}\text { Percentage (\%) of Increase } \\
\text { compared with mother plants (+) }\end{array}$} & \multirow[t]{2}{*}{$\begin{array}{l}\text { Percentage (\%) of decrease } \\
\text { compared with mother plants (-) }\end{array}$} \\
\hline Mother plants (leaves) & & & & \\
\hline Control (callus without amino acid) & 0.0 & 15.0 & & -63 \\
\hline & 50 & 160.3 & +290 & \\
\hline \multirow[t]{3}{*}{ Proline } & 100 & 57.8 & +40 & \\
\hline & 150 & 0.0 & & -100 \\
\hline & 50 & 71.8 & +75 & \\
\hline \multirow[t]{3}{*}{ Glutamine } & 100 & 68.0 & +65 & \\
\hline & 150 & 74.9 & +82 & \\
\hline & 50 & 56.0 & +36 & \\
\hline \multirow[t]{3}{*}{ Tryptophan } & 100 & 51.0 & +24 & \\
\hline & 150 & 0.0 & & -100 \\
\hline & 50 & 68.2 & +66 & \\
\hline \multirow[t]{2}{*}{ Phenyl alanine } & 100 & 57.6 & +40 & \\
\hline & 150 & 0.0 & & -100 \\
\hline
\end{tabular}


A. M. J. Al-Jibouri et al.
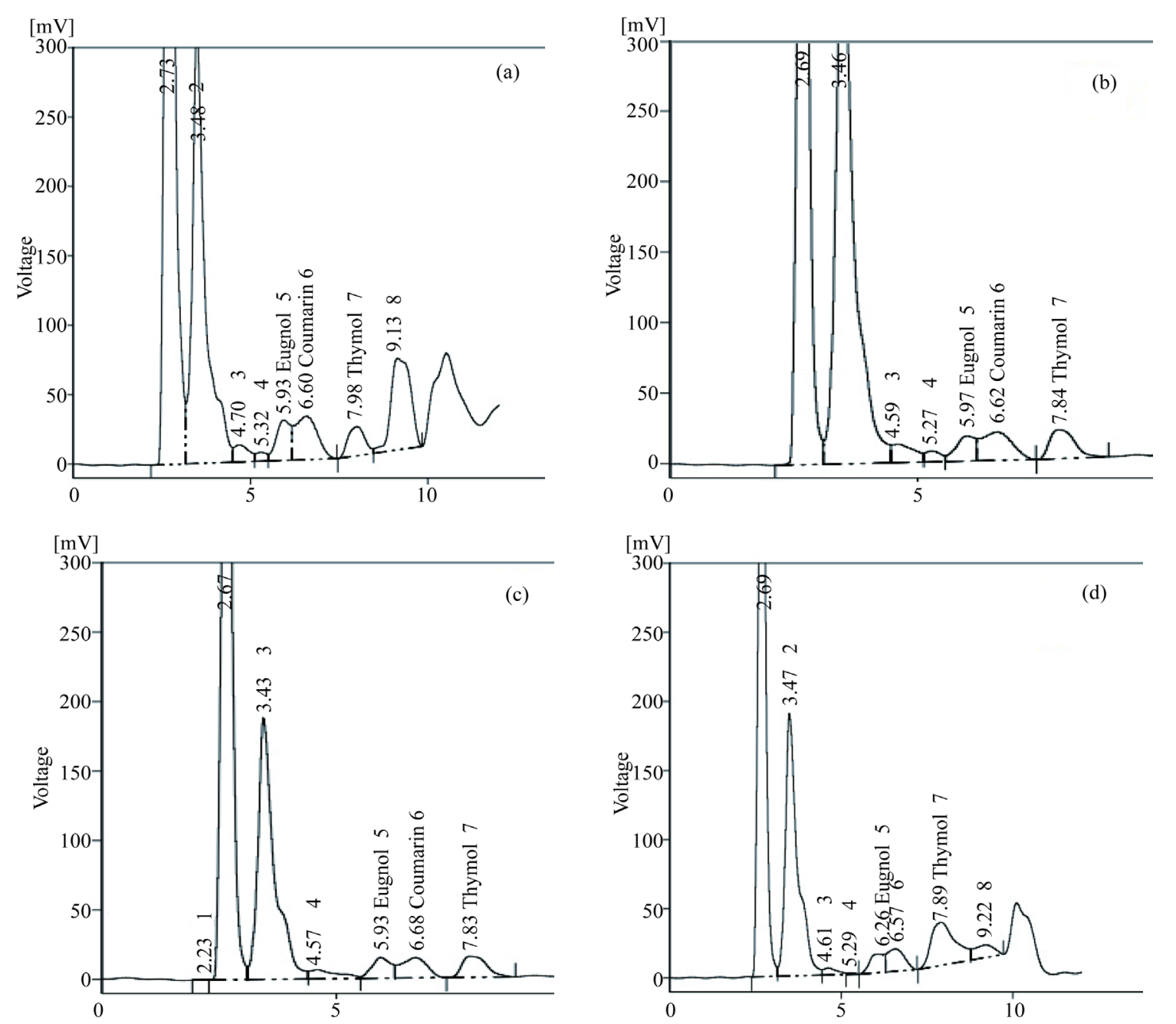

Figure 1. HPLC chromatograms for: (a) Proline (50 mg/l); (b) Glutamine (50 mg/l); (c) Tryptophan (50 mg/l); (d) Phenyl alanine $(50 \mathrm{mg} / \mathrm{l})$.

Table 5. Effect of amino acid added to MS medium on accumulation of Thymol (ppm) in callus culture of $V$. thapsus after 4 weeks of incubation.

\begin{tabular}{ccccc}
\hline Concentration of amino acid (mg/l) & Thymol (ppm) & $\begin{array}{c}\text { Percentage (\%) of Increase } \\
\text { compared with mother plants (+) }\end{array}$ & $\begin{array}{c}\text { Percentage (\%) of decrease } \\
\text { compared with mother plants (-) }\end{array}$ \\
\hline Mother plants (leaves) & & 310.0 & +67 & -17 \\
Control (callus without amino acid) & 0.0 & 519.4 & -6 & -27 \\
& 50 & 255.8 & -12 & -19 \\
Proline & 100 & 290.0 & -7 \\
& 150 & 224.4 & & -40 \\
Glutamine & 50 & 272.8 & +125 & -50 \\
& 100 & 250.0 & +390 & -4 \\
\hline
\end{tabular}


species like sorghum [24], alfalfa [25], maize [26], rice [27] and other plants to enhance somatic embryogenesis and regeneration. The aromatic amino acids Phenylalanine and Tryptophan in plants are not only essential components for protein synthesis, but also serve as precursors for a wide range of secondary metabolites that are important for plant growth [28]. Hakkim et al. [29], found that the addition of Phenylalanine into agar medium improved in rosmarinic acid yield in Ocimum sanctum cell cultures. [30] suggests that Artimisinin production can be enhanced with the manipulation of medium by different amino acids in the callus cultured. Taha et al., [31] reported that highest value of mass cell cultures and indole alkaloids production in Catharanthus roseus were achieved with modified MS medium containing $300 \mathrm{mg} / \mathrm{l}$ of either L-glutamine for mass cell induction or L-typtophane for enhancement of total indole alkaloids. Also, Ahmed et al. [14], described that the indole alkaloid content of callus tissue of Catharanthus roseus was increased by amino acids supplementation. The effect of Proline on Thymol production in Origanum vulgare and on Hyoscyamine and Scopolamine in callus culture of Hyoscyamus niger has been studied by [13] [15], they were found Proline enhanced the secondary metabolites in callus tissue. Unsuccessful attempts to induce product yield may be due to our lack of knowledge concerning the timing of addition of such compounds, their uptake, and their compartmentation in relation to the enzymes involved in their utilization [32].

\section{Acknowledgements}

This research was carried out in biotechnology research center/Al Nahrain University and funded by grants from Ministry of Higher Education and Scientific Research.

\section{References}

[1] Zohary, M. (1974) Flora of Palestine. Israel Academy of Sciences and Humanities.

[2] Sharifnia, F. (2007) Notes on the Distribution and Taxonomy of Verbascum in Iran. The Iranian Journal of Botany, 13, 30-32.

[3] Angier, B. and Foster, D.K. (2008) Field Guide to Medicinal Wild Plants. 2nd Edition, Stackpole Books, Mechanicsburg, 258.

[4] Tatli, I.I. and Akdemir, Z.S. (2004) Chemical Constituents of Verbascum L. Species. FABAD J. Pharm. Sci., 31, 85-96.

[5] Tatli, I.I. and Akdemir, Z.S. (2006) Cytotoxic Activity on Some Verbascum Species Growing in Turkey. Hacettepe University Journal of the Faculty of Pharmacy, 26, 77-85.

[6] Tatli, I.I., Akdemir, Z.S., Yesilada, E. and Kueli, E. (2008) Anti-Inflammatory and Antinociceptive Potential of Major Phenolics from Verbascum salviifolium Bioss. Zeitschrift für Naturforschung C, 63, 196-202.

[7] Turker, A.U. and Camper, N.D. (2002) Biological Activity of Common Mullein, a Medicinal Plant. Journal of Ethnopharmacology, 82, 117-125. http://dx.doi.org/10.1016/S0378-8741(02)00186-1

[8] Facciola, S.C. (1990) A Source Book of Edible Plants. Kampong Publications, Vista, 677.

[9] R.H.S. (1988)The garden. Royal Horticultural Society, volume 113.

[10] Ghorpade, R.P., Chopra, A. and Nikam, T.D. (2011) Influence of Biotic and Abiotic Elicitors on Four Major Isomers of Boswellic Acid in Callus Culture of Boswellia serrata Roxb. Plant Omics Journal, 4, 169-176.

[11] Alfen, N.K.V. (2014) Encyclopedia of Agriculture and Food Systems. 5-Volume Set, Elsevier/Academic Press, Amsterdam, 306.

[12] Masoumian, M., Arbakariya, A., Syahida, A. and Maziah, M. (2011) Effect of Precursors on Flavonoid Production by Hydrocotyle bonariensis Callus Tissues. African Journal of Biotechnology, 10, 6021-6029.

[13] Aljibouri, A.M.J., Al-Samarraei, K.W., Abd, A.S., Mageed, D.M. and Ali, A.A. (2012) Alkaloids Production from Callus of Hyoscyamusniger L. in Vitro. Journal of Life Sciences, 6, 874-882.

[14] Ahmed, F.A., Abdel-Fateh, O.M., Kobeasy, M.T. and Ahmed, O.K. (2000) Factors Affecting Growth and Indole Alkaloid Content of Catharanthus calli (Catharanthus roseus L.) Amino Acids, Casein Hydrolysate and Irradiation. Arab Journal of Biotechnology, 3, 61-70.

[15] Al-Jibouri, A.M.J., Abd, A.S., Majeed, D.M. and Ismail, E.N. (2012) Influence of Abiotic Elicitors on Accumulation of Thymol in Callus Cultures of Origanum vulgare L. Journal of Life Sciences, 6, 1094-1099.

[16] Al-Oubaidi, H.K.M. and Ameen, A.S.M. (2014) Increasing Secondary Metabolites of Calendula officinalis Using Salicylic acid in Vitro. World Journal of Pharmacy and Pharmaceutical Sciences, 13, 1146-1155.

[17] Turker, A.U., Camper, N.D. and Gurel, E. (2001) In Vitro Culture of Common Mullein (Verbascum thapsus L.). In Vi- 
tro Cellular and Developmental Biology-Plant, 37, 40-43.

[18] Murashing, T. and Skoog, F. (1962) A Revised Medium for Rapid Growth and Bioassays with Tobacco Tissue Culture. Plant Physiology, 15, 473-497. http://dx.doi.org/10.1111/j.1399-3054.1962.tb08052.x

[19] Tamura, Y. and Nishibe, S. (2002) Changes in the Concentrations of Bioactive Compounds in Plantain Leaves. Journal of Agricultural and Food Chemistry, 50, 2514-2518. http://dx.doi.org/10.1021/jf011490x

[20] Karamian, R. and Ghasemlou, F. (2014) Plant Regeneration via Organogenesis and Somatic Embryogenesis in Verbascum sinuatum L. Acta Biologica Cracoviensia Series Botanica, 56, 97-103. http://dx.doi.org/10.2478/abcsb-2014-0010

[21] Pierik, R.L.M. (1997) In Vitro Culture of Higher Plants. Springer Science and Business Media B.V., Dordrecht.

[22] Karamian, R. and Ghasemlou, F. (2012-2013) Plant Regeneration via Somatic Embryogenesis and Organogenesis in Verbascum speciosum Schard. Journal of Cell and Molecular Research, 4, 81-88.

[23] Urmantseva, V.V., Gaevskaya, O.A., Karyagina, T.B. and Bairamashvili, D.I. (2005) The Effect of Amino Acids as Components of Nutrient Medium on the Accumulation of Protoberberine Alkaloids in the Cell Culture of Thalictrum minus. Russian Journal of Plant Physiology, 52, 388-391. http://dx.doi.org/10.1007/s11183-005-0058-X

[24] Asad, S., Arshad, M., Mansoor, S. and Zafar, Y. (2009) Effect of Various Amino Acids on Shoot Regeneration of Sugarcane (Saccharum officinarum L.). African Journal of Biotechnology, 8, 1214-1218.

[25] Skokut, T.A., Manchester, J. and Schaefer, J. (1985) Regeneration in Alfalfa Tissue Culture. Plant Physiology, 79, 579-583. http://dx.doi.org/10.1104/pp.79.3.579

[26] Claparols, I., Santos, M.A. and Torné, J.M. (1993) Influence of Some Exogenous Amino Acids on the Production of Maize Embryogenic Callus and on Endogenous Amino Acid Content. Plant Cell, Tissue and Organ Culture, 34, 1-11. http://dx.doi.org/10.1007/BF00048457

[27] Grewal, D., Gill, R. and Gosal, S.S. (2006) Role of Cysteine in Enhancing Androgenesis and Regeneration of Indica Rice (Oryza sativa L.). Plant Growth Regulation, 49, 43-47.

[28] Tzin, V. and Galili, G. (2010) The Biosynthetic Pathways for Shikimate and Aromatic Amino Acids in Arabidopsis thaliana. The Arabidopsis Book 8, e0132. http://dx.doi.org/10.1199/tab.0132

[29] Hakkim, F., Kalyani, S., Essa, M., Girij, S.A. and Song, H. (2011) Production of Rosmarinic in Ocimum sanctum Cell Cultures by the Influence of Sucrose, Phenylalanine, Yeast Extract, and Methyl Jasmonate. International Journal of Biological and Medical Research, 2, 1070-1074.

[30] Zia, M., Mannan, A. and Chaudhary, M.F. (2007) Effect of Growth Regulators and Amino Acids on Artemisinin Production in the Callus of Artemisia absinthium. Pakistan Journal of Botany, 39, 799-805.

[31] Taha, H.S., El-Bahr, M.K. and Seif-El-Nasr, M.M. (2009) In Vitro Studies on Egyptian Catharanthus roseus (L.) G. Don. IV: Manipulation of Some Amino Acids as Precursors for Enhanced of Indole Alkaloids Production in Suspension Cultures. Australian Journal of Basic \& Applied Sciences, 3, 3137-3144.

[32] Constabel, F. and Vasil, I.K. (1987) Cell Culture and Somatic Cell Genetics of Plants, Vol. 4: Cell Culture in Phytochemistry. Academic Press Inc., London. 